\title{
Response to sewage sludge fertilisation in a Quercus rubra L. silvopastoral system: Soil, plant biodiversity and tree and pasture production
}

\author{
N. Ferreiro-Domínguez, A. Rigueiro-Rodríguez, M.R. Mosquera-Losada* \\ Crop Production Department, University of Santiago de Compostela, Campus de Lugo, 27002 Lugo, Spain
}

\section{A R T I C L E I N F O}

\section{Article history:}

Received 14 November 2010

Received in revised form 3 February 2011

Accepted 4 February 2011

Available online 22 March 2011

\section{Keywords:}

Agroforestry

Afforestation

Sowing

Waste

Dose

\begin{abstract}
A B S T R A C T
Silvopastoral systems are sustainable form of land management promoted by European Union. The productivity of the herbaceous and tree components in a silvopastoral system could be limited by soil fertility. The use of adequate doses of organic fertilisers like sewage sludge could enhance the productivity of both pasture and trees and promote biodiversity. The quantification of the best dose of sewage sludge to be applied in a silvopastoral system is important in order to enhance production and biodiversity in a silvopastoral system, while avoiding nitrate contamination of the ground water. This study aims to evaluate the effects of different doses of sewage sludge (100 kg total $\mathrm{N} \mathrm{ha}^{-1}, 200 \mathrm{~kg}$ total $\mathrm{N} \mathrm{ha}^{-1}$ and $400 \mathrm{~kg}$ total $\mathrm{N}$ $\mathrm{ha}^{-1}$ ) on different variables of soil (soil $\mathrm{pH}$, effective exchange capacity and the saturation percentage of $\mathrm{Al}, \mathrm{K}, \mathrm{Ca}, \mathrm{Mg}$ and $\mathrm{Na}$ ), tree growth and pasture (production, species richness and botanical composition) as compared to the fertilisation treatment in a silvopastoral system under Quercus rubra L. Sewage sludge applications initially improved soil nutrient levels (effective exchange capacity and Ca saturation percentage) and subsequently pasture production and tree growth when 200 and $400 \mathrm{~kg}$ of total N ha ${ }^{-1}$ were applied. On the other hand, the establishment of pasture and trees improved soil conditions at a medium term due to the organic matter input into the sandy soil, which increased species diversity specially at a $100 \mathrm{~kg}$ of total $\mathrm{N} \mathrm{ha}^{-1}$ dose.
\end{abstract}

(C) 2011 Published by Elsevier B.V.

\section{Introduction}

Silvopastoral systems are agroforestry systems in which tree and pasture production is combined. These systems are currently being promoted by the EU (Council Regulation 1698/2005 (EU, 2005)). Silvopastoral systems can produce social benefits, as the economic return is obtained earlier than when exclusive forest systems are used. As a result, silvopastoral systems tend to enhance the stabilisation of the rural population. Silvopastoral systems also provide environmental benefits such as the improvement of nutrient recycling, the control of soil erosion, a reduction in fire risk and an increase in carbon sequestration (Rigueiro-Rodríguez et al., 2008; Howlett et al., 2011). Furthermore, silvopastoral systems can promote biodiversity through the creation of micro-sites within the plantation, such as shaded and unshaded areas. These microsites occur as a result of the presence of trees not found in purely agronomic land. Biodiversity can be further promoted through the reduction of habitat fragmentation (Rois et al., 2006).

Quercus rubra L. is a native species from the Atlantic coast of North America that is widely used for reforestation in Galicia and

\footnotetext{
* Corresponding author. Tel.: +34 600942437; fax: +34 982285926.

E-mail address: mrosa.mosquera.losada@usc.es (M.R. Mosquera-Losada).
}

in other regions of Northern Spain (Álvarez-Álvarez et al., 2000). The exotic Quercus rubra $\mathrm{L}$. is preferred over the native Quercus robur L. by European foresters because of its faster growth, which yields earlier profits for forest farmers (Renou-Wilson et al., 2008). Quercus rubra L. is frequently used in the establishment of silvopastoral systems (Balandier and Dupraz, 1999; Lehmkuhler et al., 2003) because this species possesses an open crown that allows light to reach the pasture surface, making it compatible with pasture production. Furthermore, because it is a deciduous species, it allows better light penetration than perennial conifers during the autumn and early spring, and it provides shading during the summer. Thus, evapotranspiration is reduced, leading to enhanced pasture production as compared to pasture under conifers or on open pasture sites (Álvarez-Álvarez et al., 2000).

In Galician silvopastoral systems, the productivity (of both understory and trees) can be limited by low soil fertility as a result of increased acidity (Zas and Alonso, 2002). The use of fertilisers can modify the productivity of various components of the system (including the pasture and trees) as well as its botanical composition (Mosquera-Losada et al., 2009). One alternative that has been adopted in various countries around the world is the application of sewage sludge to soil as fertiliser (EPA, 1994). In Europe, this is regulated by the directive $86 / 278 / \mathrm{EEC}$ (EU, 1986). The use of sewage sludge as fertiliser is being promoted by the EU due to its specific 


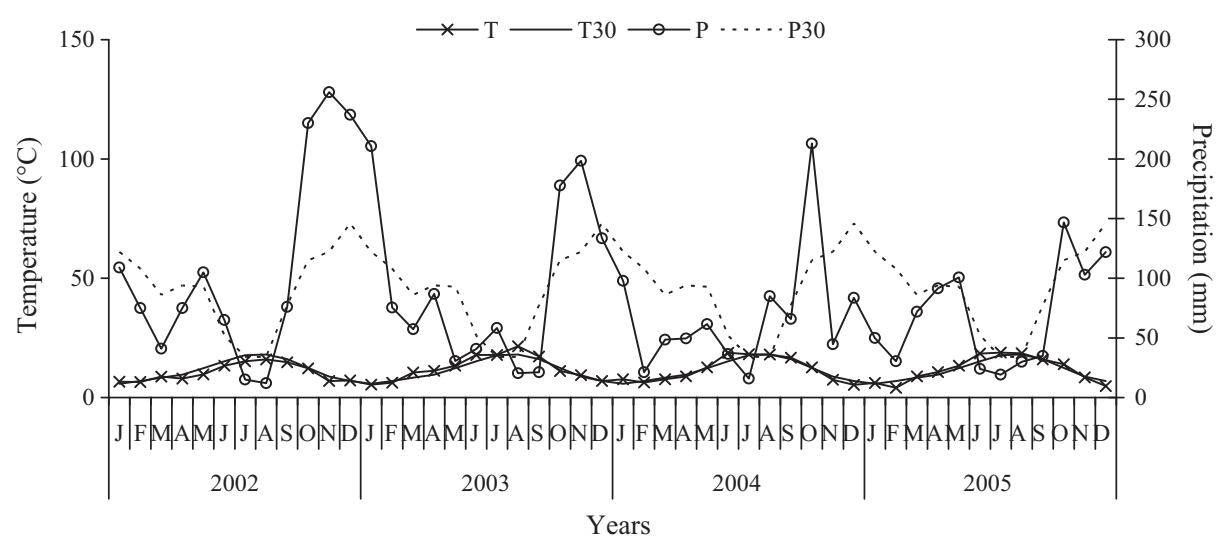

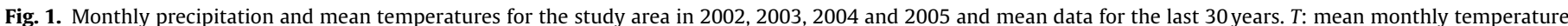
$\left({ }^{\circ} \mathrm{C}\right), T 30$ : mean temperature over the last 30 years $\left({ }^{\circ} \mathrm{C}\right), P$ : mean monthly precipitation $(\mathrm{mm})$ and $P 30$ : mean precipitation over the last 30 years $($ mm).

organic matter and macronutrients content, particularly nitrogen (N) (MMA, 2006).

The main problem with the agricultural use of sewage sludge is the higher heavy metal concentration of the sludge than in the soil (Smith, 1996). This problem is one of the set of indications regulated in Spain by the R.D. 1310/1990 (BOE, 1990) and by the European Directive 86/278/EEC (EU, 1986). Thus, the agronomic rate that can be safely applied depends both on the heavy metal concentrations in the sludge and on the nitrogen concentration and the proportion of the nitrogen that can readily be mineralised within the first year after application to the soil (Barry et al., 1986; EPA, 1994; Smith, 1996). A sewage sludge application rate exceeding the crop needs could result in nitrate contamination of the ground water by leaching. The sewage sludge should therefore be applied as close to the time of maximum nutrient uptake by crops as feasible (EPA, 1994).

The effects of the application of sewage sludge in silvopastoral systems in northwest Spain established under Pinus radiata D. Don (López-Díaz et al., 2009; Rigueiro-Rodríguez et al., 2010a; Mosquera-Losada et al., 2010a), Populus canadensis Moench (Mosquera-Losada et al., 2011) and Fraxinus excelsior L. (RigueiroRodríguez et al., 2010b) have been already studied. The objective of the present study is to evaluate the effects of different doses of sewage sludge ( $100 \mathrm{~kg}$ total $\mathrm{N} \mathrm{ha}^{-1}, 200 \mathrm{~kg}$ total $\mathrm{N} \mathrm{ha}^{-1}$ and $400 \mathrm{~kg}$ total $\mathrm{N} \mathrm{ha}^{-1}$ ) on changes in soil chemical properties, tree growth, understory production and biodiversity as compared to the no fertilisation treatment in a silvopastoral system under Quercus rubra L.

\section{Materials and methods}

\subsection{Characteristics of the study site}

The experiment was established in autumn 2001 in A Pastoriza (Lugo, Galicia, NW Spain, European Atlantic Biogeographic Region) at an altitude of $480 \mathrm{~m}$ above sea level. Fig. 1 shows the mean monthly precipitation and temperatures for 2002-2005 as well as the previous 30 years. The total annual rainfall was $1296 \mathrm{~mm}, 1111 \mathrm{~mm}, 822.9 \mathrm{~mm}$ and $824.3 \mathrm{~mm}$ in 2002, 2003, 2004 and 2005, respectively. In general, very low precipitation was observed in these years as compared with the mean for the last 30 years, and this limited pasture production and tree growth. However, in 2002 and 2003, there was a period of high precipitation from October to December. October 2004 and 2005 were also very rainy months $(212.9 \mathrm{~mm}$ and $146.8 \mathrm{~mm}$, respectively). The annual mean temperature was mild $\left(12^{\circ} \mathrm{C}\right)$ with low temperatures at the beginning and at the end of the years under study.

The experiment was carried out on abandoned agricultural land. The soil texture at the beginning of the experiment was sandy ( $91.81 \%$ sand, $4.92 \%$ silt and $3.27 \%$ clay) with a moderately acidic $\mathrm{pH}$ of 5.2 as well as high levels of soil organic matter content, total $\mathrm{N}$ and total $\mathrm{P}(10.34 \%, 0.25 \%$ and $0.09 \%$, respectively). All heavy metal concentrations in the soil (Table 1 ) were below the maximum threshold for using sewage sludge fertiliser as specified by the European Union Directive 86/278/CEE (EU, 1986) and Spanish legislation under R.D. 1310/1990 (BOE, 1990).

\subsection{Experimental design}

At the beginning of the experiment in autumn 2001, the soil was ploughed, and the pasture was sown with a mixture of Dactylis glomerata L. var. Artabro (12.5 $\left.\mathrm{kg} \mathrm{ha}^{-1}\right)$, Lolium perenne L. var. Brigantia (12.5 $\left.\mathrm{kg} \mathrm{ha}^{-1}\right)$ and Trifolium repens L. var. Huia $\left(4 \mathrm{~kg} \mathrm{ha}^{-1}\right)$. Naked-root Quercus rubra L. plants were planted at a density of 1112 trees ha $\mathrm{a}^{-1}$, with $3 \mathrm{~m} \times 3 \mathrm{~m}$ between rows. The experimental design was a randomised block with three replicas and four treatments distributed in experimental units of $144 \mathrm{~m}^{2}$ with 25 trees arranged in a frame of $5 \times 5$ trees. The treatments consisted of (a) no fertilisation $(0 \mathrm{~N})$, (b) fertilisation with anaerobically digested sludge with an input of $100 \mathrm{~kg}$ total $\mathrm{N} \mathrm{ha}^{-1}$ in March 2002 and 2003 $(100 \mathrm{~N}),(\mathrm{c})$ fertilisation with anaerobically digested sludge with an input of $200 \mathrm{~kg}$ total $\mathrm{N} \mathrm{ha}^{-1}$ in March 2002 and 2003 (200 N) and (d) fertilisation with anaerobically digested sludge with an input of $400 \mathrm{~kg}$ total $\mathrm{N} \mathrm{ha}^{-1}$ in March 2002 and 2003 (400 N). Inputs of $57.5 \mathrm{~kg} \mathrm{CO}_{3} \mathrm{Ca} \mathrm{ha}^{-1}, 115 \mathrm{~kg} \mathrm{CO}_{3} \mathrm{Ca} \mathrm{ha}^{-1}$ and $229.95 \mathrm{~kg} \mathrm{CO}_{3} \mathrm{Ca} \mathrm{ha}^{-1}$ were also applied when low (100 kg total $\left.\mathrm{N} \mathrm{ha}^{-1}\right)$, medium $(200 \mathrm{~kg}$

Table 1

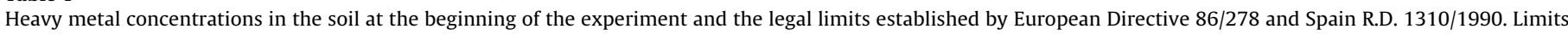

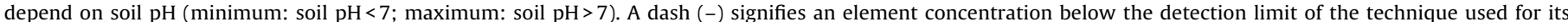
determination.

\begin{tabular}{|c|c|c|c|c|c|c|}
\hline & \multicolumn{6}{|c|}{ Heavy metal concentrations ( $\mathrm{mg} \mathrm{kg}^{-1}$ ) } \\
\hline & $\mathrm{Cd}$ & $\mathrm{Cu}$ & $\mathrm{Cr}$ & $\mathrm{Ni}$ & $\mathrm{Pb}$ & $\mathrm{Zn}$ \\
\hline Initial soil & - & 11.6 & - & 2.1 & 37.6 & 11.9 \\
\hline Spanish legal limits & $1-3$ & $50-210$ & $100-150$ & $30-112$ & $50-300$ & $150-450$ \\
\hline
\end{tabular}


Table 2

Chemical properties of the sewage sludge and legal limits established by European Directive 86/278 and Spain R.D. 1310/1990. Limits depend on soil pH (minimum: soil $\mathrm{pH}<7$; maximum: soil $\mathrm{pH}>7$ ).

\begin{tabular}{llcl}
\hline Parameters & \multicolumn{2}{l}{ Values } & \\
\cline { 2 - 4 } & $\begin{array}{l}\text { Anaerobic } \\
\text { sludge }(2002)\end{array}$ & $\begin{array}{c}\text { Anaerobic } \\
\text { sludge }(2003)\end{array}$ & $\begin{array}{l}\text { Spanish } \\
\text { legal limits }\end{array}$ \\
\hline Dry matter $(\%)$ & 22.27 & 23.82 & \\
$\mathrm{pH}$ & 7.08 & 7.49 & \\
$\mathrm{~N}\left(\mathrm{~g} \mathrm{~kg}^{-1}\right)$ & 29.7 & 25.4 & \\
$\mathrm{P}\left(\mathrm{g} \mathrm{kg}^{-1}\right)$ & 19.9 & 19.6 & \\
$\mathrm{~K}\left(\mathrm{~g} \mathrm{~kg}^{-1}\right)$ & 3 & 3.9 & $1000-1500$ \\
$\mathrm{Ca}\left(\mathrm{g} \mathrm{kg}^{-1}\right)$ & 3 & 3.2 & $1000-1750$ \\
$\mathrm{Mg}\left(\mathrm{g} \mathrm{kg}^{-1}\right)$ & 6.2 & 6.8 & $300-400$ \\
$\mathrm{Na}\left(\mathrm{g} \mathrm{kg}^{-1}\right)$ & 0.7 & 1.2 & $2500-4000$ \\
$\mathrm{Fe}\left(\mathrm{g} \mathrm{kg}^{-1}\right)$ & 26 & 13.9 & $20-40$ \\
$\mathrm{Cr}\left(\mathrm{mg} \mathrm{kg}^{-1}\right)$ & 87.9 & 81.4 & $750-1200$ \\
$\mathrm{Cu}\left(\mathrm{mg} \mathrm{kg}^{-1}\right)$ & 242.8 & 195.8 & \\
$\mathrm{Ni}\left(\mathrm{mg} \mathrm{kg}^{-1}\right)$ & 98.7 & 142.8 & \\
$\mathrm{Zn}\left(\mathrm{mg} \mathrm{kg}^{-1}\right)$ & 364.7 & 748 & \\
$\mathrm{Cd}\left(\mathrm{mg} \mathrm{kg}^{-1}\right)$ & 4.4 & 10.9 & \\
$\mathrm{~Pb}\left(\mathrm{mg} \mathrm{kg}^{-1}\right)$ & 130.6 & 78.7 & \\
$\mathrm{Mn}\left(\mathrm{mg} \mathrm{kg}^{-1}\right)$ & 311.7 & 358.8 & \\
\hline
\end{tabular}

total $\mathrm{N} \mathrm{ha}^{-1}$ ) and high (400 kg total $\mathrm{N} \mathrm{ha}^{-1}$ ) sludge were added to the soil, due to the high levels of calcium that the used sludge had.

\subsection{Sewage sludge}

Anaerobically digested sludge from a municipal waste treatment plant of Lugo was used. The required amount of sludge was calculated based on the percentage of total $\mathrm{N}$ and dry matter content (EPA, 1994), keeping in mind that approximately $25 \%$ of the total $\mathrm{N}$ from anaerobically digested sewage sludge is available in the first year after application. EU Directive 86/278/CEE (EU, 1986) and Spanish regulation R.D. 1310/1990 (BOE, 1990) regarding heavy metal concentrations in the application of sewage sludge to soil were also considered. The composition of the sewage sludge applied in 2002 and 2003 is summarised in Table 2.

\subsection{Field samplings and laboratory determinations}

Soil samples were collected at a depth of $25 \mathrm{~cm}$ in March 2003 and in January 2004, 2005 and 2006, as described in R.D. 1310/1990 (BOE, 1990). In the laboratory, soil $\mathrm{pH}$ was determined in water (1:2.5) (Faithfull, 2002). Al concentrations in the exchange complex and the exchangeable cations ( $\mathrm{K}, \mathrm{Ca}, \mathrm{Mg}$ and $\mathrm{Na}$ ) were determined by extraction with $0.6 \mathrm{~N} \mathrm{BaCl}_{2}$ (Mosquera and Mombiela, 1986). The $\mathrm{K}, \mathrm{Ca}, \mathrm{Mg}$ and Na exchangeable concentrations were measured with a VARIAN 220FS Spectrophotometer using the atomic emissions for $\mathrm{K}$ and $\mathrm{Na}$ and the absorptions for $\mathrm{Ca}$ and $\mathrm{Mg}$. Al concentrations were analysed after valoration with $0.01 \mathrm{~N} \mathrm{NaOH}$ using phenolphthaleine (1\%) in an alcohol-based solution as an indicator (Mosquera and Mombiela, 1986). The effective exchange capacity (EEC) was determined by taking the sum of $\mathrm{K}+\mathrm{Ca}+\mathrm{Mg}+\mathrm{Na}+\mathrm{Al}$ and the saturation percentage of $\mathrm{Al}, \mathrm{K}, \mathrm{Ca}, \mathrm{Mg}$ and $\mathrm{Na}$ using the quotients $\mathrm{Al} / \mathrm{EEC}, \mathrm{K} / \mathrm{EEC}$, $\mathrm{Ca} / \mathrm{EEC} \mathrm{Mg/EEC} \mathrm{and} \mathrm{Na/EEC,} \mathrm{respectively} \mathrm{(Mosquera} \mathrm{and} \mathrm{Mombiela,}$ 1986).

Tree height and diameter were measured with a graduated ruler and a calliper, respectively, in September 2006.

Estimated pasture production and botanical composition was determined by randomly collecting four samples of pasture. The four samples were cut with an electric hand clipper at a height of $2.5 \mathrm{~cm}$ per plot $(0.3 \mathrm{~m} \times 0.3 \mathrm{~m})$ in June 2002, July and December 2003, June, July and December 2004 and May, July and December 2005. One week after sampling, all plots were grazed by mature sheep (Galician breed) at a stocking rate of 50 sheep over the whole experimental area $\left(1728 \mathrm{~m}^{2}\right)$. At the laboratory, two pasture samples were dried for $72 \mathrm{~h}$ at $60^{\circ} \mathrm{C}$ and weighed to estimate pasture production. The other two samples were separated by hand to determine the proportions of the different plant species and the senescent material. These two samples were then dried for $72 \mathrm{~h}$ at $60^{\circ} \mathrm{C}$ to determine the botanical composition on a dry weight basis. The species richness was determined yearly. Annual abundance diagrams omitting the percentage of senescent material (Magurran, 1988) were completed.

\subsection{Statistical analysis}

The data on tree and pasture variables were analysed using ANOVA (proc glm procedure) following the model $Y_{i j}=\mu+T_{i}+B_{j}+\varepsilon_{i j}$, where $Y_{i j}$ is the studied variable, $\mu$ is the variable mean, $T_{i}$ indicates treatment $i, B_{j}$ is the block $j$, and $\varepsilon_{i j}$ is the error. Soil variables and species richness were analysed with repeated ANOVA (PROC GLM procedure) following the model $Y_{i j k}=\mu+A_{i}+T_{j}+B_{k}+\varepsilon_{i j k}$, where $Y_{i j k}$ is the studied variable, $\mu$ is the variable mean, $A_{i}$ is the year $i, T_{j}$ indicates treatment $j, B_{k}$ is the block $k$, and $\varepsilon_{i j k}$ is the error. The Tukey's HSD test was used for subsequent pairwise comparisons $(P<0.05 ; a=0.05)$. The statistical software package SAS (2001) was used for all analyses.

\section{Results}

\subsection{Soil characteristics}

Table 3 shows that the soil $\mathrm{pH}$, EEC and Ca saturation percentage in the soil exchange complex were significantly higher in 2006 than at the beginning of the study (2003) $(p<0.001)$. However, the saturation percentage of $\mathrm{Al}$ and $\mathrm{K}$ in the soil exchange complex decreased significantly in 2006 as compared with $2003(p<0.001)$. Furthermore, the Na saturation percentage in the soil exchange complex was higher in 2004 and 2006 than in 2003 and 2005 $(p<0.001)$.

In 2003, soil EEC and Ca saturation percentage in the soil exchange complex were affected significantly by the applied fertilisation treatments $(p<0.05)$ (Fig. 2). However, in 2004, 2005 and 2006 the effect of the treatments on EEC, Ca saturation percentage, soil $\mathrm{pH}$ and saturation percentages of $\mathrm{Al}, \mathrm{K}, \mathrm{Mg}$ and $\mathrm{Na}$ was

Table 3

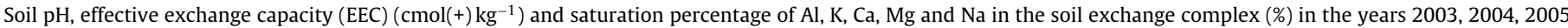
and 2006. Different letters indicate significant differences between years. ns: not-significant, ${ }^{* * *} p<0.001$, SEM: mean standard error.

\begin{tabular}{|c|c|c|c|c|c|c|}
\hline \multirow[t]{2}{*}{ Parameter } & \multicolumn{4}{|l|}{ Year } & \multirow[t]{2}{*}{ Year effect } & \multirow[t]{2}{*}{ SEM } \\
\hline & 2003 & 2004 & 2005 & 2006 & & \\
\hline $\mathrm{pH}$ & $5.4 \mathrm{bc}$ & $5.27 \mathrm{c}$ & $5.51 \mathrm{~b}$ & $5.72 \mathrm{a}$ & ${ }^{* * * *}$ & 0.04 \\
\hline $\operatorname{EEC}\left(\mathrm{cmol}(+) \mathrm{kg}^{-1}\right)$ & $4.94 \mathrm{c}$ & $5.16 c$ & $6.30 \mathrm{~b}$ & $7.84 \mathrm{a}$ & $* * *$ & 0.21 \\
\hline $\mathrm{Al}(\%)$ & $39.4 a$ & $37.1 \mathrm{a}$ & $41.11 \mathrm{a}$ & $28.65 b$ & $* * *$ & 0.01 \\
\hline $\mathrm{K}(\%)$ & $1.36 a$ & $1.36 \mathrm{a}$ & $1.15 b$ & $0.75 c$ & $* * *$ & 0.0004 \\
\hline $\mathrm{Ca}(\%)$ & $41.37 b$ & $41.25 b$ & $39.61 b$ & $52.14 a$ & $* * *$ & 0.01 \\
\hline $\mathrm{Mg}(\%)$ & 13.00 & 13.37 & 12.95 & 11.28 & ns & 0.002 \\
\hline $\mathrm{Na}(\%)$ & $4.87 \mathrm{~b}$ & $6.92 a$ & $5.18 \mathrm{~b}$ & $7.18 \mathrm{a}$ & $* * *$ & 0.002 \\
\hline
\end{tabular}



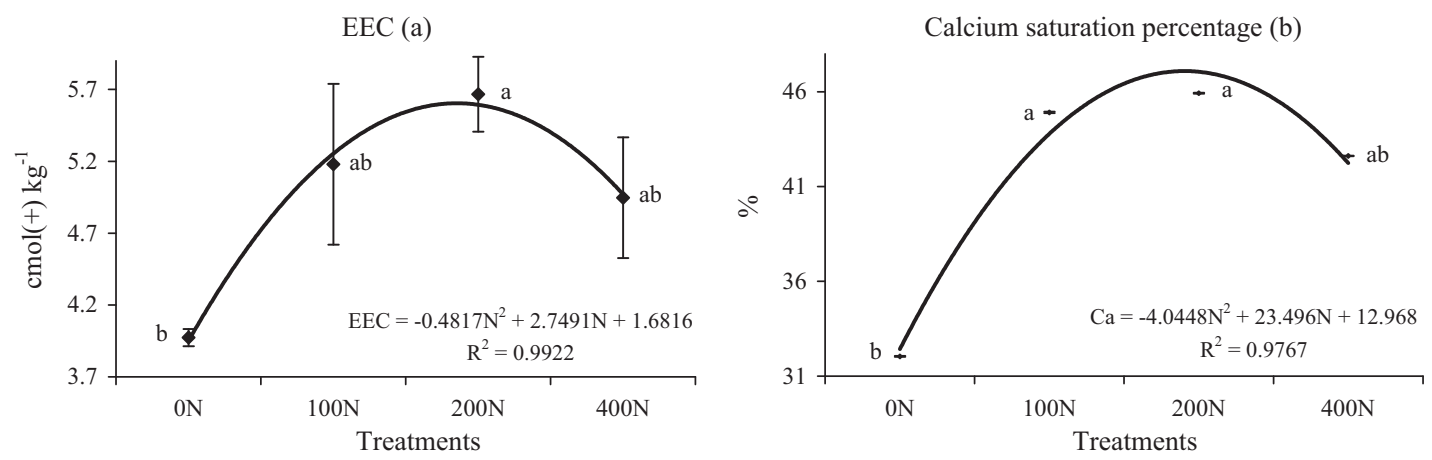

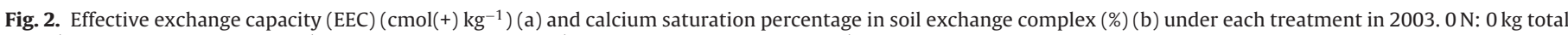

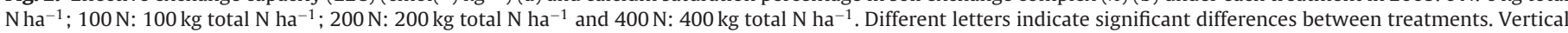
lines indicate mean standard error.

not statistically significant. The application of sewage sludge at a rate of $200 \mathrm{~kg}$ total $\mathrm{N} \mathrm{ha}^{-1}(200 \mathrm{~N})$ increased soil EEC more than when no fertilisation $(0 \mathrm{~N})$ was applied. Furthermore, the Ca saturation percentage in the soil exchange complex also increased when sewage sludge inputs had been previously done. The increase in the Ca saturation percentage was larger when low $(100 \mathrm{~N})$ and medium dose $(200 \mathrm{~N})$ of sewage sludge were applied than when no fertiliser treatment was used.

\subsection{Tree heights and diameters}

Fig. 3 shows the tree heights and diameters for each treatment in 2006. During this year, tree heights and diameters were significantly affected by the fertilisation treatment applied $(p<0.001)$. The application of a medium and a high dose $(400 \mathrm{~N})$ of sewage sludge increased more the tree heights than the no fertilisation. The tree diameters were larger under the medium doses of sewage sludge as compared with no fertilisation.

\subsection{Pasture}

\subsubsection{Production}

Annual pasture production for the different fertilisation treatments in 2002, 2003, 2004 and 2005 can be observed in Fig. 4. Pasture production was significantly affected by the dose of sewage sludge in $2003(p<0.05)$ and $2004(p<0.001)$. In 2002 and 2005, no significant differences were detected between the treatments. The highest levels of pasture production were found in 2004 (9.3-17.5 $\left.\mathrm{Mg} \mathrm{ha}^{-1}\right)$, while the lowest values were reported in 2002 (3.9-4.3 $\mathrm{Mg} \mathrm{ha}^{-1}$ ). In 2003 and 2004, the application of medium and high sewage sludge treatments increased pasture production more than the no fertilisation and low fertiliser. Cumulative pasture production during the experimental period confirmed an increased pasture production at the medium and high sewage sludge treatments in 2004 and 2005 ( $p<0.001)$ (Fig. 5).

\subsubsection{Species richness}

Fig. 6 shows that species richness was significantly higher at the end of the experiment in 2004 and 2005 than in 2002 and 2003 $(p<0.001)$. In 2002, species richness was significantly affected by the fertilisation treatments $(p<0.05)$. In this year, the low sewage sludge treatment increased species richness more than the medium fertiliser treatment. The fertilisation treatments applied also significantly effected $(p<0.05)$ the average species richness in the years 2002, 2003, 2004 and $2005\left(0 \mathrm{~N}: 6^{\mathrm{b}} ; 100 \mathrm{~N}: 8^{\mathrm{a}} ; 200 \mathrm{~N}: 6^{\mathrm{b}}\right.$; $400 \mathrm{~N}: 7^{\mathrm{b}}$ ) (different superscript letters indicate significant differences between treatments). The average species richness was higher under the low fertiliser sewage sludge treatment compared with the other treatments.

\subsubsection{Pasture abundance diagrams}

Pasture abundance diagrams for the different fertilisation treatments in 2002, 2003, 2004 and 2005 are shown in Fig. 7. From Fig. 6, the abundance diagrams confirm that the number of species was higher at the end of the study (2005) than at the beginning (2002). In 2002, the number of dicotyledonous species was higher than the number of monocotyledonous species in all treatments. However, in subsequent years (i.e., 2003, 2004 and 2005), the proportion of dicotyledonous species was higher than the proportion of monocotyledonous species in the no fertiliser treatment and the low fertiliser sewage sludge treatment. In the other treatments (200 N and $400 \mathrm{~N}$ ), there were more monocotyledonous than dicotyledonous species. Agrostis capillaris L. and Holcus lanatus L. were present in all treatments and all years. They were also the most dominant species throughout the study. A. capillaris L. was the dominant species in the no fertilisation treatment, and in the low and
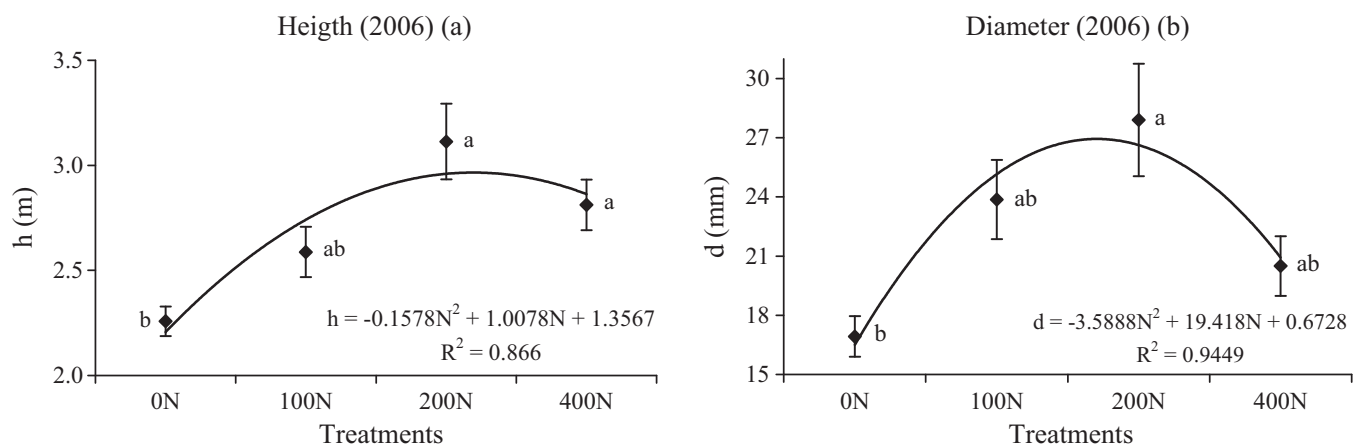

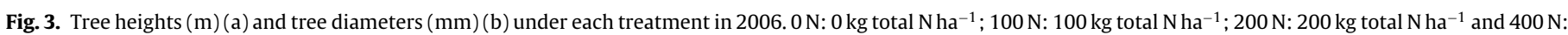
$400 \mathrm{~kg}$ total $\mathrm{N} \mathrm{ha}^{-1}$. Different letters indicate significant differences between treatments. Vertical lines indicate mean standard error. 

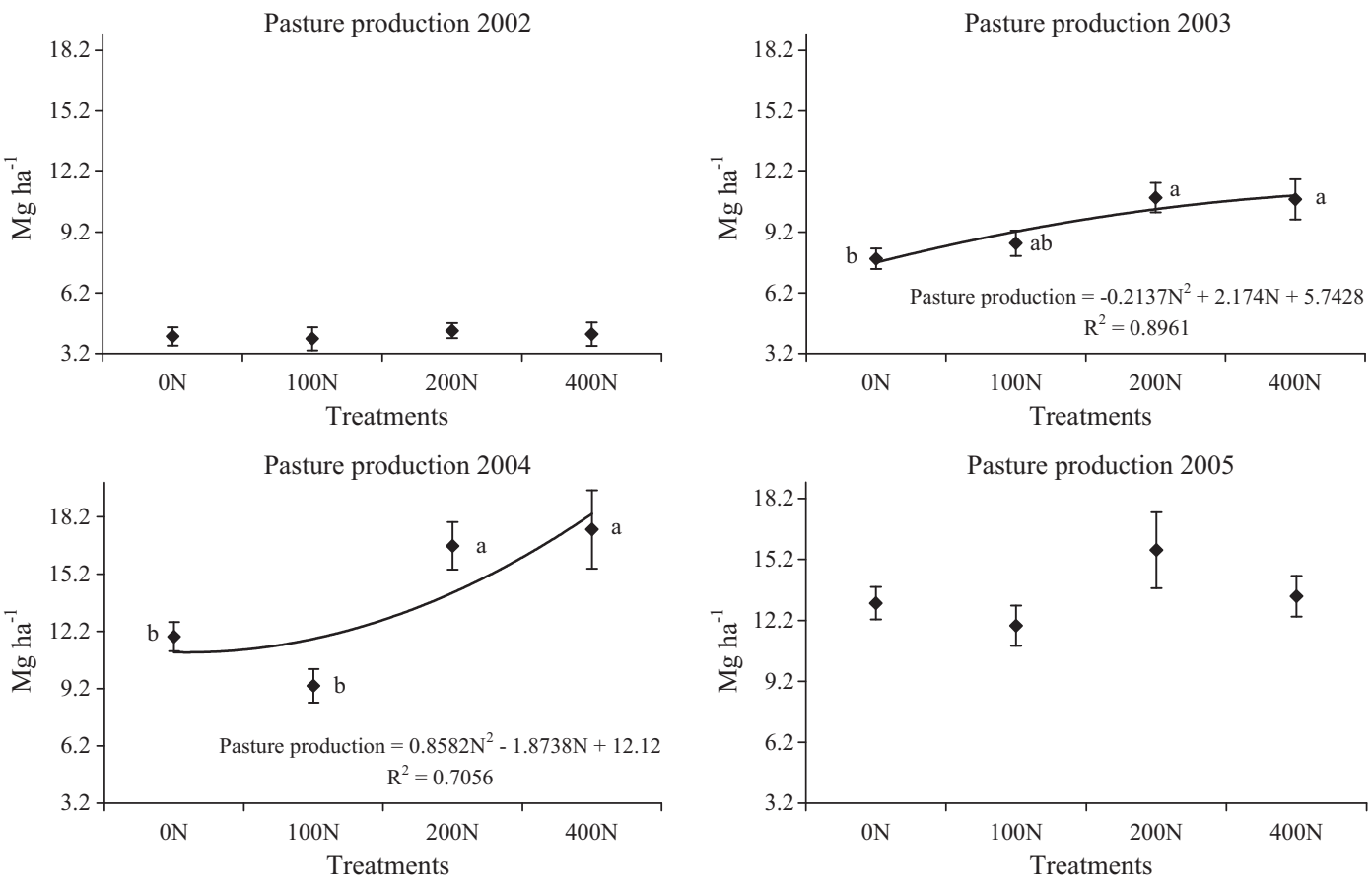

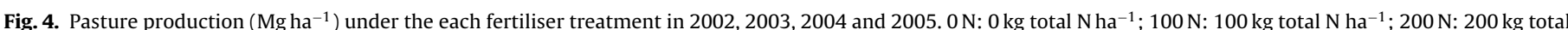

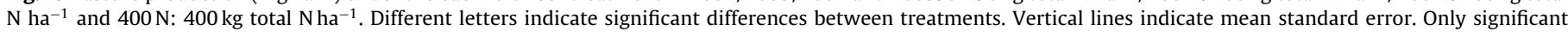
regressions are shown.

medium sewage sludge treatments. However, the proportion of $H$. lanatus L. was higher when the high sewage sludge treatment was applied as compared to the other treatments. The presence of sown species (D. glomerata L., L. perenne L. and T. repens L.) was low.

\section{Discussion}

The use of sewage sludge as a fertiliser is usually described as beneficial for plant growth due its contribution to the improvement of soil properties (Smith, 1996; Egiarte et al., 2009; MosqueraLosada et al., 2006, 2011; Rigueiro-Rodríguez et al., 2010a,b). In this study, we found an initial amelioration of different soil properties such as EEC and Ca saturation percentage. The changes in Ca saturation percentage can be explained by the $\mathrm{Ca}$ inputs from the sewage sludge application ( $100 \mathrm{~N}$ applied $57.5 \mathrm{~kg} \mathrm{CO}_{3} \mathrm{Ca} \mathrm{ha}^{-1}, 200 \mathrm{~N}$ added $115 \mathrm{~kg} \mathrm{CO}_{3} \mathrm{Ca} \mathrm{ha}^{-1}$ and $400 \mathrm{~N}$ applied $\left.229.95 \mathrm{~kg} \mathrm{CO}_{3} \mathrm{Ca} \mathrm{ha}^{-1}\right)$. However, these Ca contributions to the soil were not enough to modify other soil properties such as soil pH. López-Díaz et al. (2007) used a silvopastoral system established with Pinus radiata D. Don to show

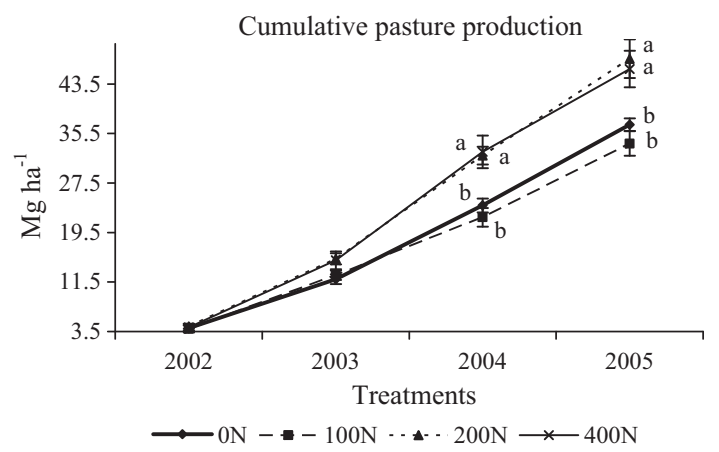

Fig. 5. Cumulative pasture production under each treatment for the period 2002-2005 $\left(\mathrm{Mg} \mathrm{ha}^{-1}\right) .0 \mathrm{~N}, 0 \mathrm{~kg}$ total $\mathrm{Nha}^{-1} ; 100 \mathrm{~N}: 100 \mathrm{~kg}$ total $\mathrm{Nha}^{-1} ; 200 \mathrm{~N}$ : $200 \mathrm{~kg}$ total $\mathrm{Nha}^{-1}$ and $400 \mathrm{~N}$ : $400 \mathrm{~kg}$ total $\mathrm{Nha}^{-1}$. Vertical lines indicate mean standard error. that soil fertility increased as the $\mathrm{pH}$ and the Ca saturation percentage increased due to the input of Ca from sewage sludge. The change in soil pH observed by López-Díaz et al. (2007) may be due to the high dose of sewage sludge used in comparison to our study. Furthermore, the sewage sludge was applied for three consecutive years, which implies a higher total $\mathrm{Ca}$ input into the soil as compared to our study ( $230 \mathrm{~kg} \mathrm{CO}_{3} \mathrm{Ca} \mathrm{ha}^{-1}, 461.4 \mathrm{~kg} \mathrm{CO}_{3} \mathrm{Ca} \mathrm{ha}^{-1}$ and $692.4 \mathrm{~kg} \mathrm{CO}_{3} \mathrm{Ca} \mathrm{ha}{ }^{-1}$ ) in the López-Díaz et al. (2007) experiment. The effects of additional Ca on soil improvement under favourable weather conditions are evident in the tree and pasture production results.

In 2006, the ranges of Quercus rubra L. heights and diameters were $2.25-3.11 \mathrm{~m}$ and $16.92-27.90 \mathrm{~mm}$, respectively. These values were greater than the tree heights $(1.38-1.99 \mathrm{~m})$ and diameters (4-10 $\mathrm{mm}$ ) reported by Kormanik et al. (2005) in a study carried

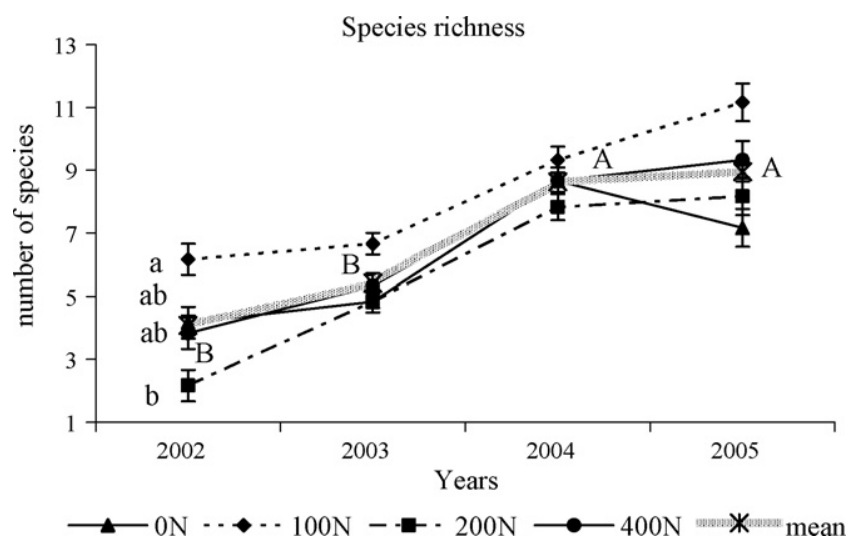

Fig. 6. Annual evolution of species richness under each treatment in 2002, 2003 2004 and $2005.0 \mathrm{~N}$ : $0 \mathrm{~kg}$ total $\mathrm{Nha}^{-1} ; 100 \mathrm{~N}: 100 \mathrm{~kg}$ total $\mathrm{Nha}^{-1} ; 200 \mathrm{~N}: 200 \mathrm{~kg}$ total $\mathrm{N} \mathrm{ha}^{-1}$ and $400 \mathrm{~N}$ : $400 \mathrm{~kg}$ total $\mathrm{N} \mathrm{ha}^{-1}$. Different capital letters indicate significant differences between years, and different lowercase letters indicate significant differences between treatment in each year. Vertical lines indicate mean standard error. 

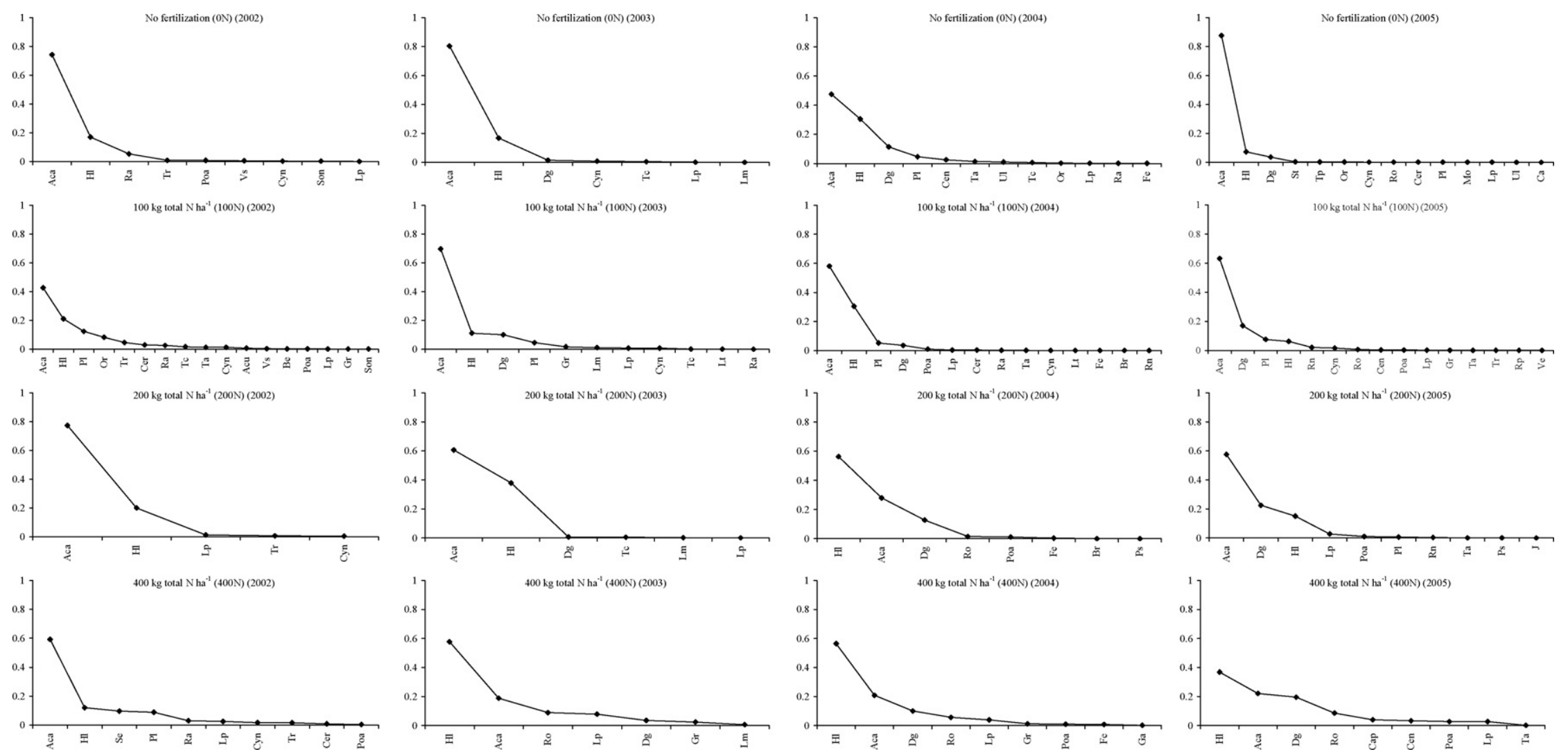

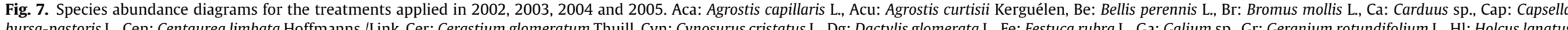

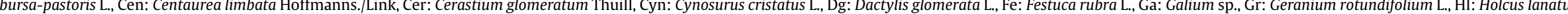

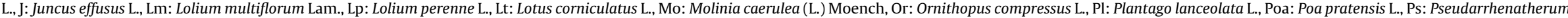

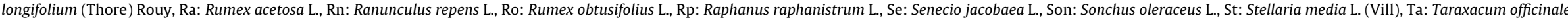
Weber Tc: Trifolium campestre Schreber, Tp: Trifolium pratense L Tr: Trifolium repens L Ul: Ulex europaeus L Ve: Veronica agrestis L and Vs: Vicia sativa L 
out in North Carolina after four years of experimentation on the same species. The largest tree heights were recorded at the medium and high sewage sludge treatments rather than the no fertilisation treatment. These results can be explained by the fact that these treatments resulted in high-nutrient inputs to the soil. Furthermore, the amount of $\mathrm{N}$ applied by these treatments may be too high for the pasture to take up but are "nevertheless" useful for the trees because the nitrate is leached to deeper soil horizons where tree roots are developed. Similar results were also reported by López-Díaz et al. (2009) and Rigueiro-Rodríguez et al. (2010a) regarding silvopastoral systems established under Pinus radiata D. Don in agrarian soils in Galicia. A reduction in soil nutrient leaching by root uptake in silvopastoral systems was also reported by Nair et al. (2007), Rigueiro-Rodríguez et al. (2008) and Mosquera-Losada et al. (2010a) as one of the main advantages of silvopastoral as compared with treeless pasture. Although the high doses of sewage sludge improved tree heights, it had no evident effect on tree diameters. This is likely due to the higher proportion of $H$. lanatus L. in this treatment as compared to the other treatments in which A. capillaris L. was the dominant species in the pasture. H. lanatus L. is a species associated with more fertile soils than A. capillaris $\mathrm{L}$. (Grime et al., 2007) and can capture more soil N, which typically limits the diameter growth of trees. In 2008, Laliberté et al. (2008) performed a study by directly seeding Quercus rubra L. on recently abandoned pastureland in Canada to find that herbaceous vegetation had no early effect on tree height. However, it slightly decreased diameter, which could have long-term biological significance. In the present experiment it was shown that diameter development depends on the type of dominant herbaceous species growing in the silvopastoral system.

Similar studies carried out in abandoned agricultural soils in Galicia reported that the average production of the pasture was between 6 and $12 \mathrm{Mg} \mathrm{ha}^{-1}$ (Mosquera-Losada et al., 1999). In this study, this production range was surpassed in the last two years of the experiment in 2004 and 2005. However, annual pasture production was less than this reported range in 2002 and was similar to this reported range in 2003. The highest levels of annual pasture production in 2004 can be explained by the lack of drought during the summer months of this year, which increased the length of the growing season. This result was also observed by Rigueiro-Rodríguez et al. (2010a) and Mosquera-Losada et al., 2011 in silvopastoral systems established in the same area under Pinus radiata D. Don and Populus canadensis Moench, respectively. Moreover, in 2002, the mean monthly temperature was lower than the mean temperature over the previous 30 years, which could have limited pasture production and prevented a response to treatments in terms of pasture production. In 2003 and 2004, the medium and high sewage sludge treatments showed higher pasture production than the other treatments. This could be due to a residual effect (EPA, 1994; Smith, 1996) from N mineralisation after sewage sludge application for two consecutive years. Mosquera-Losada et al., 2011 and Rigueiro-Rodríguez et al. (2010a) also found high pasture production when the dose of the sewage sludge was increased. In 2005 , significant differences were not detected between treatments because there was no further residual effect of sewage sludge application.

Even though a clear initial effect on soil fertility was found, pasture and tree development also affected soil characteristics and subsequently impacted species richness over time. In this study, a change in soil $\mathrm{pH}$ was observed in 2006 with respect to the beginning of the experiment (2003), but this was not a result of sewage sludge inputs. The change in soil pH can be attributed to the incorporation of pasture litter, including leaves and roots from Quercus rubra L., into the sandy soil. The trees were able to take up cations ( $\mathrm{Ca}, \mathrm{K}, \mathrm{Mg}$ ) that had been previously moved downward in the soil with percolating water and incorporate these cations again into the silvopastoral system soil after leaves fell. Soil improvement following the establishment of a tree plantation as compared to leaving open swards has been previously described by Mosquera-Losada et al., 2011. Soil EEC in our study was low and below $10 \mathrm{cmol} \mathrm{(+)}$ $\mathrm{kg}^{-1}$ soil, which can be explained by the high sand fraction in the soil at the experimental site (Brady and Weil, 2008). At the beginning of the study (2003), a change in soil EEC was observed when sewage sludge was applied (Smith, 1996). However, when sewage sludge application ceased, the effect of the treatments on EEC disappeared. This is likely due to the sandy soil in the experimental area, which would allow the cations to be easily leached through the soil profile. Moreover, it was also observed that EEC and thus most available cations were higher at the end of the experiment (2006) than in previous years; however, there were no differences between fertilisation dose treatments. The change in EEC can be explained by the establishment of the pasture and trees, which increased the organic matter input into the soil (Nieder et al., 2003); a similar phenomenon was described for Pinus radiata D. Don and Betula alba L. by Fernández-Núñez et al. (2010). In other silvopastoral systems established in the same area by Mosquera-Losada et al., 2011 and Rigueiro-Rodríguez et al. (2010b) using Populus canadensis Moench and Fraxinus excelsior L., respectively, similar results for $\mathrm{pH}$ and EEC were observed. It is important to highlight the increased Ca saturation percentage in the exchange complex and the reduction in the Al saturation percentage in 2006 as compared to 2003, 2004 and 2005 (Smith, 1996). However, the K saturation percentage in the exchange complex was lower at the end of the experiment in 2006 than in the other years of the study, and the Mg saturation percentage followed the same trend. A strong antagonism between $\mathrm{Mg}$ and Ca (O'Riordan et al., 1987; Vivekanandan et al., 1991; RigueiroRodríguez et al., 2006) and between $\mathrm{K}$ and $\mathrm{Ca}$ in the soil has been described, with both Mg and $\mathrm{K}$ being preferentially leached (Barber, 1995; Rigueiro-Rodríguez et al., 2006), which could explain these results. Moreover, reduction in $\mathrm{K}$ at the end of the experiment in 2006 and the lack of differences between treatments may also be attributed to low $\mathrm{K}$ in the sewage sludge (Mosquera-Losada et al., 2010b).

Regarding species richness, it was observed that the number of species increased in 2004 and 2005 as compared with 2002 and 2003. These results can be explained by the change in soil $\mathrm{pH}$ because the less restrictive edaphic conditions lead to an increase in the number of species (Mosquera-Losada et al., 2009). Increasing soil $\mathrm{pH}$ and low fertiliser inputs increased species richness mainly due to the increase of dicots (better developed in cation rich environments) and the reduction of monocot species, which increases their competitive advantage under more nitrogen rich environment (Grime et al., 2007). Moreover, the silvopastoral system was established under Quercus rubra L., which is a deciduous species and allows better light penetration than conifers. Species richness should be higher in this type of silvopastoral system as compared to those established under exotic conifer, such as Pinus radiata D. Don, in Galicia once tree canopy closure happens (Mosquera-Losada et al., 2006; Rigueiro-Rodríguez et al., 2011). The low sewage sludge treatment resulted in higher species richness than the medium and high sewage sludge treatments. As reported by Thompson et al. (2001), the increase in fertilisation reduces the invasion of weeds and the number of species. In contrast, A. capillaris L. was the most abundant species in the study, probably due to the grazing sheep but mostly when low doses of sewage sludge were applied. A. capillaris L. grows vegetatively from stolons (Grime et al., 2007), which spread due to damage during sheep grazing. This result was also found by Krahulec et al. (2001) in a study that took place in the Krkonose Mountains (Czech Republic). However, H. lanatus L. appeared under the high sewage sludge treatment because this species is associated with more fertile soils than A. capillaris $\mathrm{L}$. (Grime et al., 2007). In this study, a reduction in tree diameter due 
to the higher uptake of $\mathrm{N}$ of $H$. lanatus L. as compared to A. capillaris L was observed. In the present study, the presence of sown species (D. glomerata L., L. perenne L. and T. repens L.) was low because $D$. glomerata L. was not well established due to the drought and grazing sheep. Furthermore, L. perenne L. and T. repens L. require more fertile soils than that found in this study (Rigueiro-Rodríguez et al., 2000; Grime et al., 2007).

\section{Conclusion}

While the effect of sewage sludge on pasture production depended on the weather conditions of a specific year, tree growth and pasture production increased when 200 and $400 \mathrm{~kg}$ of total N $\mathrm{ha}^{-1}$ were applied. Thus, we advise application of approximately $200 \mathrm{~kg}$ of total $\mathrm{N} \mathrm{ha}^{-1}$ to enhance both components in a silvopastoral system. Sewage sludge applications initially improved soil nutrient levels (EEC and Ca saturation percentage); however, the establishment of pasture and trees improved soil conditions and increased species diversity, showing the most diversity under $100 \mathrm{~kg}$ of total $\mathrm{N} \mathrm{ha}^{-1}$ treatments.

\section{Acknowledgments}

We are grateful to CICYT and XUNTA for financial assistance and to Escuela Politécnica Superior for their facilities. It was advised also acknowledge José Javier Santiago-Freijanes, Divina VázquezVarela, Pablo Fernández Paradela and Teresa-Piñeiro-López for help with sample processing in the laboratory and the field. This research was funded in part by the Educational, Science and Technology Ministry (CICYT) and the authonomous regional government of Xunta de Galicia.

\section{References}

Álvarez-Álvarez, P., Barrio-Anta, M., Díaz-Varela, R.A., Higueras-De Marco, J., Riesco-Muñoz, G., Rigueiro-Rodríguez, A., Rodríguez-Soalleiro, R., Villarino-Urtiaga, J.J., 2000. Manual de Selvicultura de Frondosas Caducifolias. Universidad de Santiago de Compostela, Spain (accessed 25.08.10) http://www.agrobyte.com/agrobyte/publicaciones/frondosas/indice.html.

Balandier, P., Dupraz, C., 1999. Growth of widely spaced trees. A case study from young agroforestry plantations in France. Agroforest. Syst. 43, 151-167.

Barber, S.A., 1995. Soil Nutrient Bioavailability: A Mechanistic Approach, 2nd ed. John Wiley \& Sons, New York, USA.

Barry, E., Keefe, O., Axley, J., 1986. Evaluation of nitrogen availability indexes for a sludge compost amended soil. J. Environ. Qual. 15, 121-128.

BOE (Spanish Official Bolletin), 1990. Real Decreto 1310/1990 29 de Octubre de 1990, que regula la utilización de los lodos de depuración (Royal Decree 1310/1990 29th October 1990, that regulates the use of sewage sludge). Ministerio Agricultura, Pesca y Alimentación, Madrid, Spain, http://www.boe.es/boe/dias/1990/11/01/pdfs/A32339-32340.pdf （verified 11 August 2010).

Brady, N.C., Weil, R.R., 2008. The Nature and Properties of Soils, 14th ed. Prentice Hall, Upper Saddle River, NJ, USA.

Egiarte, G., Arbestain, M.C., Alonso, A., Ruíz-Romera, E., Pinto, M., 2009. Effect of repeated applications of sewage sludge on the fate of $\mathrm{N}$ in soils under Monterey pine stands. Agroforest. Syst. 216, 257-269.

EPA (Environmental Protection Agency), 1994. Land application of sewage sludge. A guide for land appliers on the requirements of the federal standards for the use of disposal of sewage sludge, 40 CFR Part 503.

EU (European Union), 1986. DOCE no. L 181 04/07/1986.Council Directive $86 / 278 /$ EEC of 12 June 1986 on the protection of the environment and, in particular of the soil, when sewage sludge is used in agriculture, http://eurlex.europa.eu/LexUriServ/LexUriServ.do?uri=CELEX: 31986L0278:ES:HTML (verified 15 December 2009).

EU (European Union), 2005. Council regulation (EC) no. 1698/2005 of September 2005 on support for rural development by the European Agricultural Fund for Rural Development, http://eurlex.europa.eu/ LexUriServ/LexUriServ.do?uri=OJ:L:2005:277:0001:0040:EN:PDF （verified 25 August 2009).

Faithfull, N.T., 2002. Methods in Agricultural Chemical Analysis. CABI Publishing, Wallingford, UK.

Fernández-Núñez, E., Rigueiro-Rodríguez, A., Mosquera-Losada, M.R., 2010. Carbon allocation dynamics one decade after afforestation with Pinus radiata D. Don and Betula alba L. under two stand densities in NW Spain. Ecol. Eng. 36, 876-890.
Grime, J.P., Hodgson, J.G., Hunt, R., 2007. Comparative Plant Ecology. A Functiona Approach to Common British Species, 2nd ed. Castlepoint Press, Dalbeattie, Scotland.

Howlett, D.S., Mosquera-Losada, M., Nair, P.K.R., Nair, V.D., Rigueiro-Rodríguez, A 2011. Soil carbon storage in silvopastoral systems and a treeless pasture in Northwestern Spain. Journal of environmental quality. 40, 1-8.

Kormanik, P., Sung, Shi-Jean, S., Zarnoch, Stanley, J., 2005. Is seedling grading beneficial to artificial regeneration of northern red oaks? In: Weigel, D.R., Van Sambeek J.W., Michler, C.H. (Eds.), Ninth Workshops on Seedling Physiology and Growth Problems in Oak Plantings. Department of Agriculture, Forest Service, North Central Research Station, St. Paul, pp. 18-20.

Krahulec, F., Skalova, H., Herben, T., Hadincova, V., Wildova, R., Pechackova, S., 2001 Vegetation changes following sheep grazing in abandoned mountain Meadows. Appl. Veget. Sci. 4, 97-102.

Laliberté, E., Cogliastro, A., Bouchard, A., 2008. Spatiotemporal patterns in seedling emergente and early growth of two oak species direct-seeded on abandoned pastureland. Ann. For. Sci. 65, 407-417.

Lehmkuhler, J.W., Felton, E.E.D., Schmidt, D.A., Bader, K.J., Garrett, H.E., Kerley, M.S 2003. Tree protection methods during the silvopastoral-system establishment in midwestern USA: cattle performance and tree damage. Agroforest. Syst. 59 $35-42$.

López-Díaz, M.L., Mosquera-Losada, M.R., Rigueiro-Rodriguez, A., 2007. Lime sewage sludge and mineral fertilization in a silvopastoral system develop in very acid soils. Agroforest. Syst. 70, 91-101.

López-Díaz, M.L., Rigueiro-Rodríguez, A., Mosquera-Losada, M.R., 2009. Influence of pasture botanical composition and fertilization treatments on tree growth. For. Ecol. Manage. 257, 1363-1372.

Magurran, A.E., 1988. Ecological Diversity and Its Measurement. Princeton University Press, London, UK.

MMA (Ministerio de Medio Ambiente), 2006. Plan integrado de residuos 2007_2015 (Integrated waste plan 2007-2015), http://www.mma.es/secciones/calidad contaminacion/residuos/planificacion_residuos/pdf/borradorpnir_anexo5.pdf (verified 16 March 2010).

Mosquera, A., Mombiela, F.A., 1986. Comparison of three methods for determination of soil Al in an unbuffered salt-extract. Commun. Soil Sci. Plant Nutr. 17, 97-113.

Mosquera-Losada, M.R., González-Rodríguez, A., Rigueiro-Rodríguez, A., 1999 Ecología y Manejo de Praderas (Ecology and Management of Grasslands). Ministerio de Agricultura, Pesca y Alimentación, Santiago de Compostela, Spain.

Mosquera-Losada, M.R., Fernández-Nuñez, M.E., Rigueiro-Rodriguez, A., 2006. Pasture, tree and soil evolution in silvopastoral system of Atlantic Europe. Forest Ecol. Manag. 232, 135-145.

Mosquera-Losada, M.R., Rodríguez-Barreira, S., López-Diaz, M.L., Fernández-Núñez, E., Rigueiro-Rodríguez, A., 2009. Biodiversity and silvopastoral system use change in very acid soils. Agric. Ecosyst. Environ. 131, 315-324.

Mosquera-Losada, M.R., Ferreiro-Domíngez, N., Rigueiro-Rodríguez, A., 2010a. Fertilization in pastoral and Pinus radiata D. Don silvopastoral systems developed in forest and agronomic soils of Northwest Spain. Agric. Ecosyst. Environ. 138, 618-628.

Mosquera-Losada, M.R., Morán-Zuloaga, D., Rigueiro-Rodríguez, A., 2011. Effects of lime and sewage sludge on soil, pasture production and tree growth in a six year old Populus canadensis Moench silvopastoral system. J. Plant Nutr. Soil Sci. 174 (1), 145-153.

Mosquera-Losada, M.R., Mũnoz-Ferreiro, N., Rigueiro-Rodriguez, A., 2010b. Agronomic characterisation of different types of sewage sludge: policy implications. Waste Manage. 30, 492-503.

Nair, V.D., Nair, P.K.R., Kalmbacher, R.S., Ezenwa, I.V., 2007. Reducing nutrient loss from farms through silvopastoral practices in coarse-textured soils of Florida, USA. Ecol. Eng. 29, 192-199.

Nieder, R., Benbi, D.K., Isermann, K., 2003. Soil organic matter dynamics. In: Benbi, D.K., Nieder, R. (Eds.), Handbook of Processes and Modelling in the Soil-Plant System. Haworth Press, London, pp. 346-408.

O'Riordan, E.G., Dodd, V.A., Fleming, G.A., Tunney, H., 1987. The fertilizer nutrient value of an anaerobically digested sewage sludge under grassland field conditions. Irish J. Agric. Food Res. 26, 199-211.

Renou-Wilson, F., Keane, M., Farrell, E.P., 2008. Establishing oak woodland on cutaway peatlands: effects of soil preparation and fertilization. Forest Ecol. Manag. 255, 728-737.

Rigueiro-Rodríguez, A., Mosquera-Losada, M.R., Gatica-Trabanini, E., 2000. Pasture production and tree growth in a young pine plantation fertilized with inorganic fertilizers and milk sewage in Northwestern Spain. Agroforest. Syst. 48, 245-256.

Rigueiro-Rodríguez, A., Mosquera-Losada, M.R., López-Díaz, M.L., 2006. Mineral concentrations in herbage and soil in a Pinus radiata silvopastoral system in north-west Spain after sewage sludge and lime application. Grass Forage Sci. $62,208-224$.

Rigueiro-Rodríguez, McAdam, A., Mosquera-Losada, M.R., 2008. Agroforestry systems in Europe: productive, ecological and social perspectives. In: Rigueiro-Rodríguez, A., McAdam, J., Mosquera-Losada, M.R. (Eds.), Advances in Agroforestry Series. Agroforestry in Europe, vol. 6. Springer, Dordrecht, The Netherlands, pp. 43-66.

Rigueiro-Rodríguez, A., Castro, S., Mosquera-Losada, M.R., 2010a. Effects of dose and period of sewage sludge application on soil, tree and pasture components in a Pinus radiata D. Don silvopastoral system. Agroforest. Syst. 79, $237-$ 247.

Rigueiro-Rodríguez, A., Ferreiro-Domínguez, N., Mosquera-Losada, M.R., 2010b. The effects of fertilization with anaerobic, composted and pelletized sewage sludge 
on soil, tree growth, pasture production and biodiversity in a silvopastoral system under ash (Fraxinus excelsior L.). Grass Forage Sci. 65, 248-259.

Rigueiro-Rodríguez, A., Mosquera-Losada. M.R., Fernández-Núñez, E., 2011. Afforestation of agricultural land with Pinus radiata D. Don and Betula alba L. in NW Spain: effects on soil pH, understorey, production and floristic diversity eleven years after establishment. Land Degrad. Environ., in press, doi:10.1002/ldr.1072.

Rois, M., Mosquera-Losada, M.R., Rigueiro-Rodríguez, A., 2006. Biodiversity indicators on silvopastoralism across Europe. European Forest Institute Technical Report 21 EFI, Joensuu, Finland, p. 68, http://www.efi.fi/publications/technicalreports/ (verified 25 August 2010).
Smith, S.R., 1996. Agricultural Recycling of Sewage Sludge and the Environment. CABI Publishing, Wallingford, UK.

Thompson, K., Hodgson, J.G., Grime, J.P., Burke, M.J.W., 2001. Plant traits and temporal scale: evidence from a 5-year invasion experiment using native species. J. Ecol. 89, 1054-1060.

Vivekanandan, M., Brown, J.R., Williams, J., Clevenger, T., Belyea, R., Tumbleson, M.E. 1991. Tolerance of forage legumes to lime-stabilized sludge. Commun. Soil Sci. Plant Nutr. 22, 449-463.

Zas, R., Alonso, M., 2002. Understory vegetation as indicators of soil characteristics in northwest Spain. For. Ecol. Manage. 171, 101-111. 